\title{
The Relationship Between the Cultural Structure of Schools and the Political Behaviors of Teachers
}

\author{
Emel Tuzel Iseri ${ }^{1}$ \\ ${ }^{1}$ Faculty of Education, Tokat Gaziosmanpaşa University, Tokat, Turkey \\ Correspondence: Emel Tuzel Iseri, Tokat Gaziosmanpaşa University, Faculty of Education, Department of \\ Educational Sciences, Tokat, Turkey. E-mail: emeltuzel@hotmail.com
}

Received: August 16, 2019

Accepted: September 12, 2019 Online Published: September 24, 2019

doi:10.5539/jel.v8n5p248

URL: https://doi.org/10.5539/jel.v8n5p248

\begin{abstract}
This study aimed to determine the relationship between the cultural structure of schools and the political behaviors that teachers exhibit within the school. The study group of this study that employed a relational screening model consisted of 489 teachers working in pre-school, elementary, and middle schools in Tokat city center in 2019. The data were collected using the School Culture Scale developed by Terzi (2005) and the Political Behaviors Scale developed by İslamoğlu and Börü (2007). The study found that teachers mostly perceived the cultural structure of their school with duty culture, which was followed by support culture and success culture. According to the perceptions of teachers, the least perceived culture in their school was the bureaucratic culture. The study concluded that as the level of teachers' perception of support, success and duty culture in their schools increased, their level of exhibiting all political behaviors including those in horizontal and vertical hierarchy decreased, whereas the bureaucratic culture that they perceived in their school increased the horizontal, vertical, and all political behaviors.
\end{abstract}

Keywords: organizational culture, school culture, political behaviors

\section{Introduction}

\subsection{Political Behavior}

It has been accepted that the classical organization theory is based on the principle of rationality in intra-organizational relations and that organizational decision-making should be based on objective, impersonal, and fair criteria within the framework of the rationality principle. However, this principle can be said to cause internal political behaviors to be overlooked based on the assumption that the objectives of the employee-organization are in harmony. Although it is based on different reasons, it is generally accepted that there are irrational principles that shape the functioning of organizations and the behavior of employees (Demirel \& Seçkin, 2009).

One of the non-rational forms of behavior which is defined in research in the field of organizational behavior is political behavior. Political behavior involves the power and impact behaviors of the individual exerted on other individuals on a micro-scale, rather than a political view on a macro scale (Ülkeryıldız, Günaydın, \& Kale, 2010). On the positive side, organizational policies mean developing relationships with other employees both up and down the chain of command. These relationships allow the fulfillment of duties and responsibilities, the manager to be aware of what is going on in the organization, and to create a network of personal business partners that will support career development. This also helps everyone to work for the interests of the organization and other employees, most appropriately. However, on the negative side, it can turn into a contention in which employees concentrate their efforts on gaining personal power at the expense of other employees and the organization upon the degeneration of internal politics (Nelson \& Economy, 2010). What is important here is that managers must accept the reality of politics to manage the policy in organizations. The emergence of political behaviors in organizations is based on two main reasons. The first is the desire of the individual to protect and defend their own interests. The second reason is the structural elements of the organization (Altıntaş, 2007).

In the literature, the notions of political behavior and political tactics are occasionally used interchangeably. Employees use a variety of tactics to achieve personal goals and interests and to influence others, regardless of the purpose of the organizations where they work. These power exercising tactics and behaviors, which have an 
impact on the efficiency and the effectiveness of the organization, can be called political behaviors (Mohammed, 2011). In other words, employees use political tactics to gain power in the organization, that is, they exhibit political behaviors.

Although Goffman did not call it direct political behaviors in 1955, he mentioned that the employees working in the organization consciously manage their impressions that they mutually imparted to each other in their relations with each other. For various reasons and expectations, employees are observed to be able to change and differentiate their behaviors in a way that they think these behaviors will affect the person while interacting with the interlocutor or interlocutors, that is, they can behave politically (Mohan-Bursal1, 2008).

According to Robbins (1994), political behavior consists of activities that are not part of the formal role of the employee in the organization, but which affect or try to affect the distribution of advantages and disadvantages in the organization. However, political behaviors are expected to be legitimate activities due to the risk that illegal political behaviors at extreme points may result in the loss of organizational membership (Yalnız, 2008). Political behaviors and individuals play a part in the process of using power as political actors or solving conflicts and uncertainties (Wilson, 2000). Behaviors, on the other hand, which are based on individual interests and which enable the individual to rise rapidly in the organization or which provide additional power (Ertekin \& Yurtsever Ertekin, 2003, cited from Heffron, 1989) can be mentioned as an example of political behavior types.

Pffeffer (1992) points out to the importance of knowing the tactics and strategies utilized for gaining and using power and having political mastery in terms of using power effectively in organizations. Organizational political behavior was defined by Mintzberg as individual or group behavior that is informal, apparently shallow, divisive, and above all, in the technical sense, it is neither endorsed by formal authority or by an accepted ideology nor is it certified expertise. Mintzberg states that political tactics within the organization are not implemented according to a set of written rules and that they are not punished as unconventional behavior, either. Therefore, it is possible to say that political behaviors are neither approved nor accepted within the organization (Ülkeryıldız, Günaydın, \& Kale, 2010). As can be seen, although it is possible to offer different definitions for political behaviors, the common feature of these definitions is that these behaviors serve the interests of the individual, help the individual to reach the desired results more quickly, but are not tolerated by the institution (İslamoğlu \& Börü, 2007). Morgan (1998) states that although politics is not discussed by the employees in the organization, it is seen as a "dirty world", which is surrounded by the methods of "conducting business" for gaining concrete interests. However, by pointing out to the fact that this point of view hinders the consideration that politics and business of politics can be a substantive element of organizational life and that it is not necessarily an optional and dysfunctional redundancy, Morgan emphasizes that the idea of politics with its original meaning stems from the view that it provides individuals a tool through which they can reconcile their differences by negotiations with and consulting to individuals with different interests. Accordingly, it can be said that evaluating the internal political behaviors as completely negative and undesired behaviors will ignore the function of policy to contribute positively to the organization through reconciliation of different interest groups. On the other hand, since internal political behaviors are attributed as "intentional behaviors", which is used to protect the interests of individual or groups or to increase their interests, they are argued to be dysfunctional at the organizational level and their negative side is usually emphasized (Demirel \& Seçkin, 2009).

Alternatively, Appelbaum and Hughes (1998) evaluate political tactics as common tactics of organization members, generally defined as "flattery" in order to achieve an upward influence and attractiveness on especially organizational management. These tactics include other enhancement, providing favors, pretending to be in agreement, and self-presentation. In the scale development study of İslamoglu and Börü (2007) conducted to determine the most politically perceived behaviors within the organization, the perceived political behaviors within the organization were found to be hypocritical behaviors, compromising behaviors, and rendering mutual interests which are seen in the horizontal hierarchy, and forming an alliance, making a grandstand play, and trying to ingratiate themselves with the top management, which are observed in the vertical hierarchy. This study took the political behaviors determined by İslamoğlu and Börü (2007) as the basis.

\subsection{Organizational Culture}

Organizations are living bodies that are made up of people interacting with each other. On the other hand, the aspects that give organization vitality such as the values that people share, the beliefs, and behaviors that people show to reach a common purpose make it necessary to look at the organization from a cultural perspective (Kiral, 2008). According to Schein (1992), the culture within the organization consists of norms, values, behaviors, rituals, and traditions.

Culture plays a binding role by tying the employees of the organization to the goals of the organization and also 
the employees to each other. Therefore, culture has an important role in the formation and success of the organizational goals, decisions, strategies, plans, and policies (Köse, Tetik, \& Ercan, 2001). Basically, organizational culture is recognized as the personality of the organization. Consequently, the reason why organizations create a unique and shared culture is a result of the fact that culture plays an active role in creating and controlling events and reducing the basic concerns of employees (Güçlü, 2003). Organizational culture affects the actions of individuals in the organization. How employees work, how they fulfill their tasks, and how they carry on their relations with coworkers and colleagues are largely determined by the organization's cultural norms, values, and beliefs (Karsl1, 2004). Peters and Waterman (1982) emphasize that the power of values and culture in organizations is much more than rules and control mechanisms within the organization (Dönmez, 2014). The characteristics of the organizational culture that various researchers have reached a consensus on can be summarized as follows (Eren, 2010):

- Organizational culture is a learned or later acquired phenomenon.

- Organizational culture should be shared among group members.

- Organizational culture is not in the form of a written text.

- The organization is manifest as beliefs and values in the thought structures, consciousness, and memory of its members.

- Organizational culture is in the form of behavioral patterns that are regularly repeated or revealed.

Culture, defined as the way of life of society, varies among societies as well as among schools. Schools have their own cultural characteristics as much as each society has its own cultural characteristics (Çelik, 2000). School culture can be shown as beliefs and values that guide the operation of the school organization (Fullan, 2007). On the other hand, school culture also shows the philosophy of the school. The organizational philosophy of the school directs the perspective of administrators, teachers, and students and provides a peaceful working environment (Taymaz, 2007). Terzi (2005), who states that school culture can be thought to have been placed on a structure ranging from bureaucratic culture to collaborative culture, divides the school culture into four categories as the supportive, bureaucratic, task, and achievement culture. In this study, school culture variables were studied under the categories created by Terzi (2005).

The achievement culture is the product of the behavioral norms that emerge in dominant organizations and the collective work of members and it can be mentioned as a culture in which the necessary things to reach organizational success are learned (Cooke \& Szumal, 2000). In organizations with a task-oriented culture, achieving a set of goals and completing the predefined task is seen as the most important value of the organization (Harrison, 1995). Faith relations, commitment, concrete support, open communication, high expectations for success, and trust are the priorities of organizations that have supportive culture (Pheysey, 1993; Kilian, 1999; Saphier \& King, 1985 cited in Tailor, 2005). In organizations with bureaucratic culture, on the other hand, rational and legal structures come to the fore. Managers have a desire to control the work done and the implementation of the rules and standards in the organization is highly important (Vries \& Miller, 1996; Kilian, 1999; Kono, 1992 cited in Terzi, 2005).

There are various studies investigating the effects of different types of organizational cultures on various behaviors of teachers such as organizational commitment (Karadağ, Baloğlu, \& Çakır, 2011; Öztürk \& Maral, 2015; Raman, Ying, \& Khalid, 2015; Wiseman, Ngirande, \& Setati, 2017), job satisfaction (Hosseinkhanzadeh, Hosseinkhanzadeh, \& Yeganeh, 2013), organizational trust (Terzi, 2016), learning (Sompranch, Prasertcharoensuk, \& Ngang, 2014), organizational citizenship behaviors (Avc1, 2016), and work motivation (Kadioğlu-Ateş \& Y1lmaz, 2018). In studies on political behaviors, Brosky (2011) aimed to reveal the negative effects of political behaviors perceived and exhibited by teachers within the school. Oruç (2015) investigated the effect of positive psychological capital of academicians on their political behaviors. Bostanc1, Akçadağ, Kahraman, and Tosun (2016) carried out a study on in-school political behaviors, and organizational DNA which is defined as the structure, culture, employee, and system cycle within the organization. Çelik and Üstüner (2018), on the other hand, studied the relationship between teachers' organizational policy perception and their organizational commitment and organizational citizenship behaviors. Nevertheless, no studies handling the effect of organizational culture observed in schools on the negative political behaviors of teachers as discussed in this study have been found. Therefore, this study is thought to contribute to the related literature.

\subsection{The Aim of the Study}

This study aimed to determine the relationship between the cultural structure of schools and the political behaviors exhibited by teachers within the school. For this purpose, the following questions were investigated: 
1) What is the cultural structure of the schools according to the teachers' perceptions?

2) What are the political behaviors exhibited by teachers within the school?

3) Is there a significant relationship between the cultural structure of schools and the political behaviors exhibited by teachers within the school?

4) Is the cultural structure of schools a significant predictor of teachers' political behaviors within the school?

\section{Method}

\subsection{Study Design}

This is a descriptive study using a relational screening survey model. Relational screening model is a research type that aims to determine the existence and/or degree of a change between two or more variables (Karasar, 2004).

\subsection{Study Group}

The study group consisted of 489 teachers selected using the convenience sampling method from 29 different schools in Tokat province in Turkey, in 2019. Demographic variables of the teachers are given in Table 1.

Table 1. Demographic variables of the participants

\begin{tabular}{llll}
\hline & & f & $\%$ \\
\hline Gender & Male & 234 & 47.9 \\
School level & Female & 255 & 52.1 \\
& Preschool & 32 & 6.5 \\
Age & Elementary & 349 & 71.4 \\
& Middle & 108 & 22.1 \\
& 25 or younger & 34 & 7.0 \\
& $26-35$ & 265 & 54.2 \\
Seniority in the present school & $36-45$ & 142 & 29.0 \\
& $46-55$ & 35 & 7.2 \\
& 56 or older & 13 & 2.7 \\
& 5 or below & 365 & 74.6 \\
& $6-10$ & 89 & 18.2 \\
Professional seniority & $11-15$ & 19 & 3.9 \\
& $16-20$ & 7 & 1.4 \\
& $21-25$ & 2 & .4 \\
& 25 or above & 7 & 1.4 \\
& 5 or below & 138 & 28.2 \\
& $6-10$ & 140 & 28.6 \\
& $11-15$ & 103 & 21.1 \\
& $16-20$ & 53 & 10.8 \\
& $21-25$ & 22 & 4.5 \\
& $26-30$ & 17 & 3.5 \\
& 31 or above & 16 & 3.3 \\
\hline
\end{tabular}

As is seen in Table 1, $47.9 \%$ of the participants were female, $71.4 \%$ were from primary schools, more than half of them were between the ages of $26-30$, the seniority of $74.6 \%$ in the present school was 5 years or below, and the professional seniority of $28.6 \%$ was between $6-10$ years.

\subsection{Data Collection Tools}

The study data were collected using a "Personal Information Form", the "School Culture Scale", and the "Political Behavior Scale". Details of the data collection tools are given below.

\subsubsection{Personal Information Form}

This form was created by the researcher to determine the demographic information of the teachers in the study group including gender, age, school level, seniority in the present school, and professional seniority.

\subsubsection{The School Culture Scale}

This scale was developed by Terzi (2005) to determine the cultural structure of schools. It consists of four dimensions including supportive culture, achievement culture, bureaucratic culture, and task culture, and is in 
5-point Likert type. Cronbach's Alpha reliability coefficient of the sub-dimensions were calculated as $.88, .82, .76$, and .74 , respectively. Cronbach's alpha reliability coefficient for the overall scale was .84 .

\subsubsection{Political Behaviors Scale}

This scale was developed by İslamoğlu and Börü (2007) to determine political behaviors within an organization. The scale is made up of 6 sub-dimensions including hypocritical behaviors, compromising behaviors, and rendering mutual interests which are seen in the horizontal hierarchy, and forming an alliance, making a grandstand play, and trying to ingratiate themselves with the top management, which are observed in the vertical hierarchy. This is a 5-point Likert-type scale. It is used to let teachers evaluate their own political behaviors exhibited within the school. Cronbach's alpha reliability coefficient for the overall scale is .94 .

\section{Results}

1) The first sub-problem of the research was determined as "What is the cultural structure of the schools according to the teachers' perceptions?" Mean scores $(\overline{\mathrm{x}})$ and standard deviation $(\mathrm{S})$ values of the supportive, achievement, bureaucratic, and task culture dimensions observed in schools according to teacher perceptions are given in Table 2.

Table 2. Cultural structure of schools according to teacher perceptions $(\mathrm{N}=489)$

\begin{tabular}{lll}
\hline & $\overline{\mathrm{x}}$ & $\mathrm{S}$ \\
\hline Supportive culture & 3.9215 & .75541 \\
Achievement culture & 3.8960 & .78373 \\
Bureaucratic culture & 3.0329 & .65453 \\
Task culture & 4.1115 & .68171 \\
\hline
\end{tabular}

As seen in Table 2, according to the teachers' perceptions, the cultural structure of their school was explained mostly by "task culture" ( $\overline{\mathrm{x}}=4.1115, \mathrm{~S}=.68171)$, which was followed by "supportive culture" $(\overline{\mathrm{x}}=3.9215, \mathrm{~S}$ $=.75541)$, "achievement culture" ( $\overline{\mathrm{x}}=3.8960, \mathrm{~S}=.78373)$, and "bureaucratic culture" $(\overline{\mathrm{x}}=3.0329, \mathrm{~S}=.65453)$, respectively.

2) The second sub-problem of the research was determined as "What are the political behaviors exhibited by teachers within the school?" Mean scores $(\overline{\mathrm{x}})$ and standard deviation $(\mathrm{S})$ values regarding political behaviors exhibited by teachers within the school are given in Table 3.

Table 3. Political behaviors exhibited by teachers within the school $(\mathrm{N}=489)$

\begin{tabular}{llll}
\hline Political Behaviors & Political Behavior Dimensions & $\overline{\mathrm{x}}$ & $\mathrm{S}$ \\
\hline Political behaviors in horizontal hierarchy & Showing compromising behaviors & 1.2161 & .42135 \\
$(\overline{\mathrm{x}}=1.2601, \mathrm{~S}=.40391)$ & Showing hypocritical behaviors & 1.2836 & .42804 \\
& Rendering mutual interests & 1.2807 & .56908 \\
& Making a grandstand play & 1.2033 & .41783 \\
Political behaviors in vertical hierarchy & Forming an alliance & 1.4524 & .59454 \\
& Trying to ingratiate themselves with the top management & 1.4833 & .70307 \\
& & 1.3199 & .41361 \\
\hline
\end{tabular}

As seen in Table 3, teachers resort to political behaviors in the vertical hierarchy $(\overline{\mathrm{x}}=1.3796, \mathrm{~S}=.47400)$ more than the political behaviors in the horizontal hierarchy $(\overline{\mathrm{x}}=1.2601, \mathrm{~S}=.40391)$. In other words, it can be said that teachers behave more politically against school administrators than their colleagues. The most frequent political behavior of the teachers in the vertical hierarchy was determined as "trying to ingratiate themselves with the top management" $(\overline{\mathrm{x}}=1.4833, \mathrm{~S}=.70307)$, while the most political behavior towards their colleagues was found to be "showing hypocritical behaviors" $(\overline{\mathrm{x}}=1.2836, \mathrm{~S}=.42804)$.

3) The third sub-problem of the study was determined as "Is there a significant relationship between the cultural structure of schools and the political behaviors exhibited by teachers within the school?" Pearson's Product Moment Correlation Coefficients showing the relationships between schools' cultural structure and teachers' political behaviors are given in Table 4. 
Table 4. The relationships between schools' cultural structure and teachers' political behaviors

\begin{tabular}{|c|c|c|c|c|c|c|c|c|c|c|c|c|c|}
\hline Dimensions & 1 & 2 & 3 & 4 & 5 & 6 & 7 & 8 & 9 & 10 & 11 & 12 & 13 \\
\hline 1. Supportive c. & 1 & $.843^{* *}$ & .044 & $.551^{* *}$ & $-.186^{* *}$ & $-.174^{* *}$ & $-.156^{* *}$ & $-.156^{* *}$ & $-.191^{* *}$ & $-.096^{*}$ & $-.216^{* *}$ & $-.158^{* *}$ & $-.196^{* *}$ \\
\hline 2. Achievement $\mathrm{c}$. & & 1 & .046 & $.522^{* *}$ & $-.180^{* *}$ & $-.208^{* *}$ & $-.156^{* *}$ & $-.149^{* *}$ & $-.205^{* *}$ & -.062 & $-.232^{* *}$ & $-.139^{* *}$ & $-.193^{* *}$ \\
\hline 3. Bureaucratic c & & & 1 & $.280^{* *}$ & $.092^{*}$ & .077 & $.126^{* *}$ & $.143^{* *}$ & .079 & $.154^{* *}$ & $.096^{*}$ & $.173^{* *}$ & $.146^{* *}$ \\
\hline 4. Task c. & & & & 1 & $-.172^{* *}$ & $-.143^{* *}$ & -.089 & -.085 & -.084 & -.079 & $-.150^{* *}$ & $-.101^{*}$ & $-.131^{* *}$ \\
\hline 5. Compromising b. & & & & & 1 & $.764^{* *}$ & $.699^{* *}$ & $.460^{* *}$ & $.566^{* *}$ & $.602^{* *}$ & $.884^{* *}$ & $.695^{* *}$ & $.830^{* *}$ \\
\hline 6. Hypocritical b. & & & & & & 1 & $.646^{* *}$ & $.448^{* *}$ & $.486^{* *}$ & $.541^{* *}$ & $.847^{* *}$ & $.645^{* *}$ & $.783^{* *}$ \\
\hline 7. Making a grandstand play & & & & & & & 1 & $.624^{* *}$ & $.643^{* *}$ & $.549^{* *}$ & $.773^{* *}$ & $.826^{* *}$ & $.851^{* *}$ \\
\hline 8. Forming an alliance & & & & & & & & 1 & $.619^{* *}$ & $.439^{* *}$ & $.609^{* *}$ & $.818^{* *}$ & $.766^{* *}$ \\
\hline 9. Rendering mutual interests & & & & & & & & & 1 & $.407^{* *}$ & $.838^{* *}$ & $.649^{* *}$ & $.781^{* *}$ \\
\hline 10. Trying to ingratiate w.m. & & & & & & & & & & 1 & $.592^{* *}$ & $.839^{* *}$ & $.770^{* *}$ \\
\hline 11. Horizontal h. & & & & & & & & & & & 1 & $.774^{* *}$ & $.932^{* *}$ \\
\hline 12. Vertical h. & & & & & & & & & & & & 1 & $.951^{* *}$ \\
\hline 13. All Political B. & & & & & & & & & & & & & 1 \\
\hline
\end{tabular}

Table 4 shows that there was a low level negatively significant relationship between teachers' political behavior scores obtained by evaluating all political behaviors together and the perceived supportive culture $(r=-196)$, achievement culture $(\mathrm{r}=-193)$, and task culture $(\mathrm{r}=-.131)$. Also, there was a low level positively significant relationship between teachers' political behavior scores obtained by evaluating all political behaviors together and the perceived bureaucratic culture $(\mathrm{r}=.146)$. Accordingly, as the level of teachers' perception of supportive, achievement, and duty culture increased within their school, their political behaviors were found to decrease, whereas the bureaucratic culture they perceived within their school were determined to increase their political behaviors.

A low level negatively significant relationship was observed between teachers' political behaviors exhibited in the horizontal and vertical hierarchy and the achievement culture $(r=-.232, r=-.139)$, supportive culture $(r$ $=.216, \mathrm{r}=-.159)$, and task culture $(\mathrm{r}=-.150, \mathrm{r}=-.101)$. On the other hand, there found to be a low level positively significant relationship between the political behaviors of the teachers in the horizontal and vertical hierarchies and the perceived bureaucratic culture within their school $(r=.096, r=.173)$. Accordingly, it can be said that the increase in the achievement, supportive, and duty culture perceived by the teachers within the school decreased the political behaviors of the teachers in the horizontal and vertical hierarchy, while the increase in the perceived bureaucratic culture within their school increased the political behaviors exhibited in the horizontal and vertical hierarchies.

A low level negatively significant relationship was found between the task culture that teachers perceived the most within their school and showing compromising behaviors $(r=-.172)$ and hypocritical behaviors $(r=-.143)$. No significant relationship was found between task culture and all other political behavior dimensions. Accordingly, it can be said that as the duty culture observed within school increases, teachers resort to compromising and hypocritical behaviors less frequently.

There was a low level negatively significant relationship between the support culture, which was the second most perceived culture by the teachers within their school, and all sub-dimensions of political behaviors including compromising behaviors $(\mathrm{r}=-.186)$, hypocritical behaviors $(\mathrm{r}=-.174)$, making a grandstand play $(\mathrm{r}=$ -156), forming an alliance $(r=-156)$, rendering mutual interests $(r=-191)$, and trying to ingratiate themselves with the top management $(\mathrm{r}=-.096)$. Accordingly, it can be said that as the support culture perceived by teachers within their school increases, their level of exhibiting all political behaviors decreases.

A low level negatively significant relationship was found between the achievement culture, which was the third-most perceived culture of teachers within their school, and all sub-dimensions of political behaviors, excluding "trying to ingratiate themselves with the top management", including compromising behaviors $(\mathrm{r}=$ $-.180)$, hypocritical behaviors $(r=-.208)$, making a grandstand play $(r=-156)$, forming an alliance $(r=-149)$, and rendering mutual interests $(\mathrm{r}=-205)$. Accordingly, it can be stated that as the achievement culture perceived by teachers within their school increases, their level of displaying all political behaviors, apart from "trying to ingratiate themselves with the top management", decreases.

The study found a low level positively significant relationship between the bureaucratic culture, which was the least perceived culture of teachers within their school, and political behaviors in the sub-dimensions such as compromising behaviors $(\mathrm{r}=.092)$, making a grandstand play $(\mathrm{r}=.126)$, forming an alliance $(\mathrm{r}=.143)$ and 
trying to ingratiate themselves with the top management $(\mathrm{r}=.154)$. Accordingly, as the bureaucratic culture that teachers perceive within their school increases, the levels of exhibiting political behaviors arising in the form of "compromising behaviors", "making a grandstand play", "forming an alliance", and "trying to ingratiate themselves with the top management" can be said to increase.

4) The fourth sub-problem of the study was determined as "Is the cultural structure of schools a significant predictor of teachers' political behaviors within the school?" Table 5 shows the results of the multiple linear regression analyses carried out between the total scores of all political behaviors including those exhibited in the horizontal and vertical hierarchy, and the supportive, achievement, task, and bureaucratic school cultures.

Table 5. The predictability of teachers' political behaviors by the cultural structure of the school

\begin{tabular}{|c|c|c|c|c|c|c|c|c|}
\hline & Variables & $\mathrm{B}$ & $\begin{array}{l}\text { Standard } \\
\text { Error }\end{array}$ & $\beta$ & $\mathrm{t}$ & $\mathrm{p}$ & $\begin{array}{l}\text { Double } \\
\mathrm{r}\end{array}$ & $\begin{array}{l}\text { Partial } \\
\mathrm{r}\end{array}$ \\
\hline Political Behaviors in & Constant & 1.624 & .131 & - & 12.427 & .000 & - & - \\
\hline \multirow[t]{5}{*}{ Horizontal Hierarchy } & Supportive culture & -.022 & .045 & -.041 & -.489 & .625 & -.022 & -.021 \\
\hline & Achievement culture & -.084 & .042 & -.163 & -1.984 & .048 & -.090 & -.087 \\
\hline & Bureaucratic culture & .079 & .028 & .127 & 2.766 & .006 & .125 & .121 \\
\hline & Task culture & -.046 & .033 & -.078 & -1.394 & .164 & -.063 & -.061 \\
\hline & \multicolumn{8}{|c|}{$\mathrm{R}=.266, \mathrm{R}^{2}=.071, \mathrm{~F}_{(4-484)}=9.190, \mathrm{p}=.00$} \\
\hline Political Behaviors in & Constant & 1.485 & .154 & - & 9.646 & .000 & - & - \\
\hline \multirow[t]{5}{*}{ Vertical Hierarchy } & Supportive culture & -.070 & .053 & -.111 & -1.312 & .190 & -.060 & -.058 \\
\hline & Achievement culture & -.004 & .050 & -.006 & -.073 & .942 & -.003 & -.003 \\
\hline & Bureaucratic culture & .148 & .034 & .205 & 4.421 & .000 & .197 & .195 \\
\hline & Task culture & -.065 & .039 & -.094 & -1.678 & .094 & -.076 & -.074 \\
\hline & \multicolumn{8}{|c|}{$\mathrm{R}=.252, \mathrm{R}^{2}=.063, \mathrm{~F}_{(4-484)}=8.171, \mathrm{p}=.00$} \\
\hline \multirow[t]{6}{*}{ Political Behaviors (All) } & Constant & 1.554 & .134 & - & 11.617 & .000 & - & - \\
\hline & Supportive culture & -.046 & .046 & -.084 & -.993 & .321 & -.045 & -.044 \\
\hline & Achievement culture & -.044 & .043 & -.083 & -1.010 & .313 & -.046 & -.044 \\
\hline & Bureaucratic culture & .113 & .029 & .179 & 3.894 & .000 & .174 & .171 \\
\hline & Task culture & -.056 & .034 & -.092 & -1.646 & .100 & -.075 & -.072 \\
\hline & \multicolumn{8}{|c|}{$\mathrm{R}=.266, \mathrm{R}^{2}=.071, \mathrm{~F}_{(4-484)}=9.195, \mathrm{p}=.00$} \\
\hline
\end{tabular}

Table 5 shows that the political behaviors of the teachers in the horizontal hierarchy were found to be significantly predicted in terms of supportive, achievement, bureaucratic, and task culture of their schools (R $=.266, \mathrm{p}<.01)$. These predictive characteristics explained $7 \%$ of the variance of the teachers' political behaviors in the horizontal hierarchy. According to the standardized regression coefficients, the relative importance of the schools' cultural characteristics in teachers' political behaviors that they exhibit in the horizontal hierarchy was lined up as achievement culture $(\beta=-.163)$, bureaucratic culture $(\beta=.127)$, task culture $(\beta=-.078)$, and supportive culture $(\beta=-.041)$.

The t-test results related to the significance of the regression coefficients indicated that the achievement culture $(\mathrm{t}=-1.984, \mathrm{p}<.05)$ and bureaucratic culture $(\mathrm{t}=2.766, \mathrm{p}<.05)$ observed in schools were significant predictors of teachers' political behaviors in the horizontal hierarchy. Meanwhile, supportive culture $(t=-.489, p>.05)$ and task culture ( $\mathrm{t}=-1.394, \mathrm{p}>.05)$ were found to not be significant predictors of the level of teachers' political behaviors in the horizontal hierarchy.

Accordingly, it can be said that the increase in the achievement culture and the decrease in the bureaucratic culture perceived by teachers in their school is of significance in terms of decreased political behaviors of teachers in the horizontal hierarchy.

The political behaviors of the teachers in the vertical hierarchy were determined to be significantly predicted in a low level in terms of supportive, achievement, bureaucratic, and task culture of their school $(\mathrm{R}=252, \mathrm{p}<.01)$. These predictive characteristics explained $6 \%$ of the variance of teachers" political behaviors exhibited in the vertical hierarchy. According to standardized regression coefficients, the relative importance of cultural characteristics of schools in teachers' political behaviors exhibited in vertical hierarchy was lined up as bureaucratic culture $(\beta=.205)$, supportive culture $(\beta=-.111)$, task culture $(\beta=-.094)$, and achievement culture $(\beta=-.006)$.

The t-test results related to the significance of the regression coefficients showed that the bureaucratic culture $(\mathrm{t}$ $=4.421, \mathrm{p}<.01)$ observed in schools was a significant predictor of teachers' political behaviors exhibited in the 
horizontal hierarchy. On the other hand, the supportive culture $(\mathrm{t}=-1.312, \mathrm{p}>.05)$, achievement culture $(\mathrm{t}=$ $-.073, p>.05)$, and task culture $(t=-1.678, p>.05)$ were found to have no significant predictive effect on the level of exhibiting political behaviors by the teachers in the vertical hierarchy.

Correspondingly, it can be stated that the decrease in the bureaucratic culture in the school is important for teachers to exhibit less political behaviors in the vertical hierarchy.

All the political behaviors exhibited by the teachers in their school were determined to be significantly predicted in a low level in terms of supportive, achievement, bureaucratic, and task culture of their schools $(\mathrm{R}=.266, \mathrm{p}$ $<.01$ ). These predictive characteristics explained $7 \%$ of the variance of all political behaviors exhibited by teachers within their school. According to the standardized regression coefficients, the relative importance of cultural characteristics of schools in overall political behaviors of teachers exhibited in their school was lined up as bureaucratic culture $(\beta=.179)$, task culture $(\beta=-.092)$, supportive culture $(\beta=-.084)$, and achievement culture $(\beta=-.083)$.

The results of the t-test related to the significance of the regression coefficients revealed that the bureaucratic culture ( $\mathrm{t}=3.894, \mathrm{p}<.01)$ observed in schools was found to be a significant predictor of all political behaviors exhibited by the teachers within their school. On the contrary, the supportive culture $(t=-.993, p>.05)$, achievement culture $(\mathrm{t}=-1.010, \mathrm{p}>.05)$, and task culture $(\mathrm{t}=-1.646, \mathrm{p}>.05)$ were determined to have no significant predictive effect on the level of exhibiting all political behaviors by the teachers.

Accordingly, it can be said that the decrease in the bureaucratic culture in the school is of significance in ensuring that teachers exhibit less all political behaviors in their school.

\section{Discussion}

As a result of the research, teachers were determined to perceive the cultural structure of their schools mostly through the task culture, which was followed by the supportive culture and achievement culture. According to the perceptions of the teachers, the least perceived culture in their school was bureaucratic culture. According to Bursalığlu (1982), one of the important characteristics of the school is that it is an organization with bureaucratic structure. In addition, Doğan (2004) emphasizes that bureaucracy makes up the backbone of the education system in Turkey. On the other hand, the results of the research indicate that the bureaucratic culture structure of the school is observed to be less common than its other cultural features. In this context, strict bureaucratic organizational structures that overlook interpersonal informal relations and interactions can be said to be impractical for utilization as an effective management tool in school organizations where intensive human relations come to the fore (Tüzel, 2010). Furthermore, strong and healthy relationships between teachers at school are recognized as a fundamental component of school effectiveness and teacher development (Shah, 2012).

Individuals can come to organizations not only with the physical characteristics, skills, and inclinations necessary for the organization, but also with attitudes, personality traits, emotions, and enthusiasm that can be considered negative aspects for the organization (Aydın, 2005). Regardless of position and status, all members of organizations can be said to be players in games of politics, and every employee often has some political behaviors that they resort to (Vecchio, 1988, cited in Hoy \& Miskel, 2010). The results of this study, too, laid out that teachers resorted to some political behaviors in vertical and horizontal hierarchies within their school. The results demonstrate that teachers resort to political behaviors in the vertical hierarchy more than the political behaviors in the horizontal hierarchy. In other words, teachers can be said to behave more politically towards school administrators than their colleagues. While the most resorted political behavior by teachers in the vertical hierarchy was found to be "trying to ingratiate themselves with the top management", the highest level of political behavior that teachers showed towards their colleagues was determined to be hypocritical behaviors. In a similar study, Korucuoğlu and Şentürk (2018) found that teachers working in schools preferred moderate and mild political tactics towards the managerial field.

As a result of the research, as the levels of teachers' perception of supportive, achievement, and task culture within their school increased, their level of exhibiting all political behaviors including those in the horizontal and vertical hierarchy was found to decrease, whereas the bureaucratic culture that they perceived within their schools was determined to increase the horizontal, vertical and all political behaviors that they exhibited. In a study investigating the general outcomes of studies on bureaucracy, Buluç (2009) reported that the performance and efficiency of the organizations where bureaucracy operates effectively was high and that generally, it positively affected the variables between which the relationships are tested, but that the finding of the present study that increased bureaucratic culture increased political behaviors in the schools can be shown as a negative effect of bureaucratic culture. Accordingly, while operating the bureaucratic culture at school, administrators 
should not ignore the fact that creating a bureaucratic, rigid, prescriptive, and inflexible culture may lead to an increase in political behaviors in the school.

Crippen (2005) emphasizes that a more collegial, cooperative, transformative, and service-based approach is gaining importance in schools. According to Gurr, Drysdale and Mulford (2005), successful school administrators develop a culture of collegiality, cooperation, support, and trust. On the other hand, there is a greater chance that individual goals may be transformed into shared goals in schools that have a strong and sharing culture because there is collective consciousness in strong organizational cultures (Çelik, 1997; Turan \& Bektaş, 2013). The results of this study showed that as teachers' perceived support culture increased within their school, their levels of exhibiting all political behaviors were found to decrease, and that as their perceived achievement culture increased, their levels of showing all political behaviors, except for "trying to ingratiate themselves with the top management", were determined to decrease as well. In addition, the study concluded that the increase in the achievement culture and the decrease in the bureaucratic culture that teachers perceived within their schools were important for teachers to exhibit less political behaviors in the horizontal hierarchy in the school. Accordingly, it can be suggested that when school administrators sustain the support and achievement culture within schools, this will reduce political behaviors and allow the creation of a more transparent and positive communication environment between people in both horizontal and vertical hierarchies, and that school administrators should elaborate on shaping the organizational culture knowing that bureaucratic culture has an adverse effect.

\section{References}

Altıntaş, F. Ç. (2007). Örgüt yapısının örgütsel politika ve işlem adaleti üzerine etkisinin yapısal denklem modellemesi yardımıla analizi. Anadolu University Journal of Social Sciences, 7(2), 151-168. https://doi.org/10.1501/SBFder_0000002297

Appelbaum, S. H., \& Hughes, B. (1998). Ingratiation as a political tactic: Effects within the organization. Management Decision, 36(2), 85-95. https://doi.org/10.1108/00251749810204160

Avc1, A. (2016). Örgüt kültürünün örgütsel vatandaşlık davranışlarına etkisi. Journal of Human Sciences, 13(3), 5373-5398. https://doi.org/10.14687/jhs.v13i3.4264

Aydın, M. (2005). Eğitim yönetimi (7th ed.). Ankara: Hatiboğlu Yayınları.

Bozkurt, B. A., Akçadağ, T., Kahraman, Ü., \& Tosun, A. (2016). Okulların DNA profili ile okul içi politik davranışlar arasındaki ilişki. Journal of Human Sciences, 13(3), 5693-5705. https://doi.org/10.14687/jhs.v13i3.4307

Brosky, D. (2011). Micropolitics in the school: Teacher leaders' use of political skill and influence tactics. The International Journal of Educational Leadership Preparation, 6(1), 1-11. Retrieved from https://files.eric.ed.gov/fulltext/EJ972880.pdf

Buluç, B. (2009). İlköğretim okullarında bürokratik okul yapısı ile okul müdürlerinin liderlik stilleri arasındaki ilişki. Eğitim ve Bilim, 34(152), 71-86. Retrieved from http://egitimvebilim.ted.org.tr/index.php/EB/article/view/9

Bursalığlu, Z. (1982). Okul yönetiminde yeni yapı ve davranış. Ankara: Ankara Üniversitesi Eğitim Fakültesi Yayınları.

Cooke, R. A., \& Szumal, J. L. (2000). Using the organizational culture inventory to understand the operating cultures of organizations. In N. M. Ashkanasy, C. P. M. Wilderom \& M F. Peterson (Eds.), Hand-book of organizational culture \& climate (pp. 147-162). Thousand Oaks, CA: Sage.

Crippen, C. (2005). The democratic school: First to service, then to lead. Canadian Journal of Educational Administration and Policy, 47, 1-17. https://eric.ed.gov/?id=EJ846732

Çelik, O. T., \& Üstüner, M. (2018). Ortaokul öğretmenlerinin örgütsel politika algıları ile örgütsel bağl1lıkları ve örgütsel vatandaşlık davranışları arasındaki ilişki. Hacettepe University Journal of Education. Advance online publication. https://doi.org/10.16986/HUJE.2018044109

Çelik, V. (2000). Okul kültürü ve yönetimi (2. Baskı). Ankara: Pegem Yayılları.

Demirel, Y., \& Seçkin, Z. (2009). Örgüt içi politik davranışların tespiti üzerine Kırgızistan'da sağlık sektöründe bir araştırma. Orta Asya ve Kafkasya Araştırmalar Dergisi, 3(7), 143-161. http://www.acarindex.com/dosyalar/makale/acarindex-1423910563.pdf

Doğan, İ. (2004). Toplum ve eğitim. Ankara: Pegem A Yayıncılık. 
Dönmez, B. (2014). Bir eğitim kurumu olarak okul. In Eğitim bilimine giriş (Eds. Y. Özden \& S. Turan., 4th ed., pp. 87-108). Ankara: Pegem Akademi.

Eren, E. (2010). Örgütsel davranıs ve yönetim psikolojisi (12. Basım). İstanbul: Beta Basım Yayım A.Ş.

Ertekin, Y., \& Yurtsever, E. G. (2003). Örgütsel politika ve taktikler (Birinci basım). Ankara: Türkiye ve Orta Doğu Amme İdaresi Enstitüsü Yayınları.

Fullan, M. (2007). The new meaning of educational change. New York: Routledge.

Gurr, D., Drysdale, L., \& Mulford, B. (2005). Succesful principal leadership: Australian case studies. Journal of Educational Administration, 43(6), 539-551. https://doi.org/10.1108/09578230510625647

Güçlü, N. (2003). Örgüt kültürü. Manas Üniversitesi Sosyal Bilimler Dergisi, 6, 147-159. Retrieved from http://journals.manas.edu.kg/mjsr/oldarchives/Vol03_Issue06_2003/295.pdf

Harrison, R. (1995). The collected papers of Roger Harrison. San Franciso, CA: Jossey-Bass.

Hosseinkhanzadeh, A. A., Hosseinkhanzadeh, A., \& Yeganeh, T. (2013). Investigate relationship between job satisfaction and organizational culture among teachers, Procedia - Socialand Behavioral Sciences, 84, 832836. https://doi.org/10.1016/j.sbspro.2013.06.656

Hoy, W. K., \& Miskel, C. G. (2010). Eğitim yönetimi teori, araştırma ve uygulama (Translated book, Ed. S. Turan). Nobel Akademi Yayıncilık.

İslamoğlu, G., \& Börü, D. (2007). Politik Davranış boyutları: Bir ölçek geliştirme çalışması. Akdeniz İ.İ.B.F. Dergisi, 14, 135-153. https://dergipark.org.tr/download/article-file/372626

Kadıoğlu-Ateş, H., \& Yılmaz, P. (2018). Investigation of the work motivation levels of primary school teachers. Journal of Education and Training Studies, 6(3), 184-196. https://doi.org/10.11114/jets.v6i3.2948

Karadağ, E., Baloğlu, N., \& Çakır, A. (2011). A path analysis study of school culture and teachers' organisational commitment. Policy Futures in Education, 9(5), 573-585. https://doi.org/10.2304/pfie.2011.9.5.573

Karasar, N. (2004). Bilimsel araştırma yöntemi (13th ed.). Ankara: Nobel Yayın Dağıtım.

Karsl1, M. D. (2004). Yönetsel etkililik (2nd ed.). Ankara: Pegem A Yayınc1lık.

Kıral, E. (2008). Kültür olarak örgütler. In A. Balcı (Ed.), Örgüt mecazları. Ankara: Ekinoks Yayınevi.

Korucuoğlu, T., \& Şentürk, İ. (2018). Örgütsel güç oyunları ve örgütsel muhalefet arasındaki ilişki (İlkokul ve ortaokullarda görev yapan öğretmen görüşleri bağlamında). Hacettepe Üniversitesi Eğitim Fakültesi Dergisi. Advance online publication. https://doi.org/10.16986/HUJE.2018045306

Köse, S., Tetik, S., \& Ercan, C. (2001). Örgüt kültürünü oluşturan faktörler. Celal Bayar Üniversitesi İ.İ.B.F. Yönetim ve Ekonomi Dergisi, 7(1), 219-242. Retrieved from http://dergipark.ulakbim.gov.tr/yonveek/article/view/5000069018

Mohammed, A. E. (2011). Örgüt kültürü ve psikolojik iklimin politik davranış algllamaları üzerinde etkileri: Kayseri'de bir araştırma. Unpublished msters thesis, Erciyes Üniversitesi, Sosyal Bilimler Enstitüsü, İşletme Anabilim Dalı.

Mohan, B. Y. (2009). Örgütsel politikanın işleyişi: Örgütsel politika algısı ve politik davranış arasındaki iliş̧kiler. Unpublished PhD thesis, Dokuz Eylül Üniversitesi, Sosyal Bilimler Enstitüsü, İşletme Anabilim Dalı.

Morgan, G. (1998). Yönetim ve örgüt teorilerinde metafor. İstanbul Mess Yayın.

Nelson, B., \& Economy, P. (2010). Yöneticilik for dummies - Meraklssina (Translated book, Ed. A. Ü. Şensoy, 2nd ed.). İstanbul: Doğan Egmond Yayıncılık ve Yapımcılık Tic. A.Ş.

Oruç, E. (2015). Pozitif psikolojik sermayenin politik davranışlara etkisi: Akademisyenler üzerine bir araştırma. Yayınlanmamış doktora tezi, Sakarya Üniversitesi, Sosyal Bilimler Enstitüsü.

Öztürk, Z., \& Maral, S. (2015). The school culture predictor of organizational commitment of elementary and secondary vice (Yalova Sample). Journal of Business Research, 7(2), 63-86. https://doi.org/10.20491/isader.2015215734

Pfeffer, J. (1992). Güç merkezli yönetim - Örgütlerde politika ve nüfuz. İstanbul: Boyner Holding Yayınları.

Raman, A., Ying, L. T., \& Khalid, R. (2015). The Relationship between culture and organizational commitment among Chinese primary school teachers. Mediterranean Journal of Social Sciences, 6(2), 93-100. https://doi.org/10.5901/mjss.2015.v6n2s5p93 
Schein, E. H. (1992). Organizational culture and leadership (2nd ed.). San Francisco: Jossey - Bass Publishers.

Shah, M. (2012). The importance and benefits of teacher collegiality in schools A literature review. Procedia Social and Behavioral Sciences, 46, 1242-1246. https://doi.org/10.1016/j.sbspro.2012.05.282

Sompranch, K., Prasertcharoensuk, T., \& Ngang, T. K. (2014). The impact of organizational culture on Teacher Learning. Procedia - Social and Behavioral Sciences, 186, 1038-1044. https://doi.org/10.1016/j.sbspro.2015.04.020

Taymaz, H. (2007). Illköğretim ve ortaöğretim okul müdürleri için: Okul yönetimi (8th ed.). Ankara: Pegem Akademi.

Terzi, A. R. (2005). İlköğretim okullarında örgüt kültürü. Kuram ve Uygulamada Eğitim Yönetimi, 43, 423-442. Retrieved from http://www.kuey.net/index.php/kuey/article/view/394

Terzi, A. R. (2016). Teachers' perception of organizational culture and trust relation. International Journal of Organizational Leadership, 5, 338-347. https://doi.org/10.33844/ijol.2016.60448

Tüzel, E. (2010). İlkögrretim okullarının bürokratikleşme düzeyi ile öğretmenlerin örgütsel bağllllkları arasındaki ilişki (Ankara ili örneği). Unpublished master thesis, Gazi Üniversitesi, Eğitim Bilimleri Enstitüsü, Ankara.

Ülkeryıldız, E., Günaydın, H. M., \& Kale, S. (2010). Proje organizasyonlarında politik taktikler. 1. Proje ve Yapım Yönetim Kongresi, 29 Eylül-1 Ekim 2010, ODTÜ, Ankara.

Ülkeryıldız, E., Günaydın, H. M., \& Kale, S. (2010a). Mimari proje organizasyonlarında politik davranışın karanlık yüzü: Politik taktikler. Yapı Dergisi, 347(5), 120-123.

Wilson, J. W. (2000). The relation of individual political behavior, perceptions of organizational politics, and organizational citizenship behavior: Integrating organizational justice. Unpublished $\mathrm{PhD}$ thesis, University of Houston.

Wiseman, N., Ngirande, H., \& Setati, S. T. (2017). Existing organizational culture typologies and organizational commitment at a selected higher education institution in South Africa. Investment Management and Financial Innovations, 14(2), 242-251. https://doi.org/10.21511/imfi.14(2-1).2017.09

Yalnız, A. (2008). Politika metaforu. In A. Balcı (Ed.), Örgüt mecazları. Ankara: Ekinoks Yayınevi.

\section{Copyrights}

Copyright for this article is retained by the author, with first publication rights granted to the journal.

This is an open-access article distributed under the terms and conditions of the Creative Commons Attribution license (http://creativecommons.org/licenses/by/4.0/). 